ISSN 0258-7122

Bangladesh J. Agril. Res. 40(3): 491-500, September 2015

\title{
EFFECT OF SOWING DATE AND PLANT SPACING ON SEED PRODUCTION OF CAULIFLOWER
}

\author{
M. F. HOSSAIN ${ }^{1}$, N. ARA ${ }^{2}$, M. R. UdDIN ${ }^{3}$ \\ M. R. ISLAM ${ }^{4}$ AND M. G. AZAM ${ }^{5}$
}

\begin{abstract}
The experiment was conducted at Regional Agricultural Research Station, Ishurdi, Pabna during rabi season of 2011-2012 and 2012-2013 to find out the appropriate sowing date and optimum plant spacing for seed production of cauliflower (var. BARI Phulcopi-1). Four sowing dates viz. 20 September, 1 October, 10 October and 20 October and three plant spacing viz. $60 \mathrm{~cm} \times 50 \mathrm{~cm}$, $60 \mathrm{~cm} \times 60 \mathrm{~cm}$ and $60 \mathrm{~cm} \times 70 \mathrm{~cm}$ were used as treatment variables. Significant variation in seed yield and yield contributing characters of cauliflower were observed due to execution of different sowing dates and plant spacing. Number of branches plant ${ }^{-1}$, number of pods plant ${ }^{-1}$ and number of seeds pod ${ }^{-1}$ showed the highest in 1 October sowing as a result the highest seed yield $\left(361.69 \mathrm{kgha}^{-1}\right)$ was obtained from same date of sowing. Sowing on 10 October and 20 October reduced seed yield drastically compared to that obtained from 1 October sowing. The lowest seed yield (188.54 $\left.\mathrm{kgha}^{-1}\right)$ was obtained from 20 October sowing. On the contrary, closer spacing $(60 \mathrm{~cm} \times 50 \mathrm{~cm})$ produced the highest seed yield $\left(315.88 \mathrm{kgha}^{-1}\right)$ and the wider spacing $(60 \mathrm{~cm} \times 70 \mathrm{~cm})$ produced the lowest seed yield $\left(254.07 \mathrm{kgha}^{-1}\right)$. However, combination of 1 October sowing with 60 $\mathrm{cm} \times 50 \mathrm{~cm}$ plant spacing produced the highest seed yield $\left(414.81 \mathrm{kgha}^{-1}\right)$ due to higher number of seeds $\operatorname{pod}^{-1}$. The seed yield decreased after 10 October sowing irrespective of plant spacing. So, early sowing (1 October) with closer spacing $(60 \mathrm{~cm} \times 50 \mathrm{~cm})$ would be economically profitable for cauliflower seed production in North-Western part of Bangladesh.
\end{abstract}

Keywords: Cauliflower, sowing, spacing, yield and seed.

\section{Introduction}

Cauliflower (Brassica oleracea var. botrytis L.) is a biannual and herbaceous vegetable crop belonging to the family Cruciferae. It is one of the popular winter vegetables in Bangladesh. Cauliflower thrives best in a cool moist climate and it does not withstand very low temperature or too much heat (Din et al., 2007). The temperature in the country remains higher up to mid October after which gradually comes down in mid-December and extends up to mid-February. The

${ }^{1}$ Senior Scientific Officer, Bangladesh Agricultural Research Institute, RARS, Ishwardi, Pabna, ${ }^{2}$ Principal Scientific Officer, Bangladesh Agricultural Research Institute, Gazipur, ${ }^{3}$ Principal Scientific Officer, Bangladesh Agricultural Research Institute, RARS, Ishwardi, Pabna, ${ }^{4}$ Senior Scientific Officer, Bangladesh Agricultural Research Institute, RARS, Ishwardi, Pabna, ${ }^{5}$ Scientific Officer, Bangladesh Agricultural Research Institute, PRC, Ishwardi, Pabna, Bangladesh. 
temperature increases sharply thereafter. Optimum plant spacing is important for crop production through efficient utilization of light, nutrients and water by the plants. In some cases higher plant population adversely affect yield per unit area hampering vegetative and reproductive growth of plant specially head size and delay in seed maturity. So, it is essential to maintain optimum plant spacing for maximum seed yield of cauliflower. Baloch (1994) recommended that relatively wide spacing $(60 \mathrm{~cm} \times 60 \mathrm{~cm})$ promotes earliness and larger heads, but yield and number of curds usually increased by close spacing $(45 \mathrm{~cm} \times 45 \mathrm{~cm})$. Increase the plant density limits the availability of space for lateral growth, resulting in increase in plant height (Pandita et al., 2005). Seeds of cauliflower are produced in the country in a small scale but the maximum amount of seeds of cauliflower is imported from other countries. The meteorological data for the last 10 years indicated that the crop suffer from cold injury during the month of January (Anon, 2007) which resulted low yield of crop. The optimum temperature for cauliflower withstands is 10 to $15^{\circ} \mathrm{C}$ (Din et al., 2007) but in the north-western part of the country, the night temperature falls even below $5-6^{\circ} \mathrm{C}$ which affects crop yield loss. Early sowing recorded maximum vegetative growth and higher yield than late planting (Alam et al., 2010). Lavanya et al., (2014) recommended that early sowing ( $1^{\text {st }}$ October) with closer spacing is suitable treatment combination for higher seed yield of radish. So, it is needed to optimize sowing date for quality seed production of cauliflower. Keeping in view, the present experiment was conducted to find out the suitable sowing date and determine the optimum plant spacing for seed production of cauliflower.

\section{Materials and Method}

The experiment was carried out at Regional Agricultural Research Station, Ishurdi, Pabna during rabi season of 2011-12 and 2012-13. The initial soil samples were collected from the experimental field for a depth of $0-15$ cmprior to application of fertilizers. The nutrient status of soil of the experimental plot was determined at the Soil Science Lab of Soil Science Division, Bangladesh Agricultural Research Institute, Joydebpur, Gazipur. Results of soil analysis are presented in Table 1. Four sowing dates viz. 20 September, 1 October, 10 October and 20 October and three plant spacing viz. $60 \mathrm{~cm} \times 50 \mathrm{~cm}, 60 \mathrm{~cm} \times 60$ $\mathrm{cm}$ and $60 \mathrm{~cm} \times 70 \mathrm{~cm}$ were used as treatment variables. The treatments were factorial combination of the two factors and the experiment was conducted using a randomized complete block design with three replications. The unit plot size was $10 \mathrm{~m} \times 1.2 \mathrm{~m}$. Seeds of variety BARI Phulcopi- 1 were sown in the nursery beds at an interval of 10 days started from 20 September. Beds were immediately irrigated with the help of watering cane. After germination, when the seedlings were attained at a height of $3 \mathrm{~cm}$ then the seedlings were transplanted in the other nursery beds $10 \mathrm{~cm}$ apart for proper growth and development of the seedlings. Thirty days old seedlings were transplanted in the evening time in the 
experimental plot according to the treatment. Healthy seedlings of uniform size were selected for planting. Before transplantation, the nursery beds were irrigated so that the seedlings could be easily uprooted from the beds without any damage of the root. After one week of transplantation, dead seedlings were replaced by planting fresh seedlings to obtain a uniform stand. The land was fertilized with well decomposed cowdung @ 15 tha $^{-1}$ and 120, 55, 100, 15 1.5, 2 and $1 \mathrm{kgha}^{-1} \mathrm{~N}$ P K S B Zn and Mo, respectively as a source of Urea, TSP, MoP, Gypsum, Boric acid, Zinc sulphate and Sodium molybdate, respectively. Curds with hollow stem disorder is a major problem in cauliflower production and is associated with Mo deficiency. So, Mo application is a crucial factor for yield and quality as well as to control curds with hollow stem disorder. Total amount of cow dung, TSP, gypsum, zinc sulphate, boric acid and sodium molybdate were applied in the plot during final land preparation. Urea and MoP were applied in four equal installments at 20, 40,60 and 90 days after planting. After transplantation, the experimental plot was irrigated by watering cane and second irrigation (flood irrigation) was done 3 days after transplantation. After this, irrigations were done after fertilizer application and as and when required. Three weeding were done for weed control at 20,40 and 60 DAT. In the early stage of transplantation damping off disease was occurred in early sowing but serious in late sowing and it was controlled by spraying Bavistin @ $2 \mathrm{~g} \mathrm{liter}^{-1}$ water. In the seed maturation stage, the plant was attacked by Cercospora leaf spot disease and controlled by spraying Rovral @ $2 \mathrm{~g} \mathrm{liter}^{-1}$ water. Scooping (removing centre portion of curd) was done when it is fully formed to help the easy emergence of the flower stalks. The flower stalks were supported with bamboo stakes to avoid lodging. Ten plants were selected randomly for data collection. Harvesting was done on 16 to 30 March in 2012 and 14 to 30 March in 2013 when the pods were brown in colour. The collected data were analyzed statistically and the means were separated by Duncan Multiple Range Test (DMRT). The crop received $273 \mathrm{~mm}$ and $351 \mathrm{~mm}$ total rainfall during crop period of 2011-12 and 2012-13, respectively. A little bit more rainfall occurred in 2012-13. The mean monthly maximum air temperature was $30.66{ }^{\circ} \mathrm{C} \& 30.96{ }^{\circ} \mathrm{C}$ and minimum was $18.36{ }^{\circ} \mathrm{C}$ and $16.92{ }^{\circ} \mathrm{C}$ during crop period of $2011-12$ and 2012-13, respectively. The lowest mean (10 days) maximum $\left(21^{\circ} \mathrm{C}\right)$ and minimum $\left(13^{\circ} \mathrm{C}\right)$ air temperature was occurred in 20 to 31 December (Fig. 1).

Table1. Chemical properties of initial soils of the experimental field.

\begin{tabular}{|c|c|c|c|c|c|c|c|c|c|c|c|c|}
\hline \multirow[t]{2}{*}{$\mathrm{pH}$} & \multirow{2}{*}{$\begin{array}{l}\mathrm{OM} \\
(\%)\end{array}$} & $\mathrm{Ca}$ & $\mathrm{Mg}$ & K & $\begin{array}{l}\text { Total } \\
\mathrm{N} \%\end{array}$ & $\mathrm{P}$ & $S$ & B & $\mathrm{Cu}$ & $\mathrm{Fe}$ & $\mathrm{Mn}$ & $\mathrm{Zn}$ \\
\hline & & \multicolumn{3}{|c|}{ meq $100^{-1} \mathrm{~g}$} & & \multicolumn{7}{|c|}{$\mu \mathrm{gml}^{-1}$} \\
\hline 7.16 & 1.35 & 11.20 & 1.6 & 0.12 & 0.049 & 11 & 15 & 0.2 & 1.5 & 18 & 11 & 1.9 \\
\hline \multicolumn{2}{|l|}{ Criti } & 2.0 & 0.8 & 0.2 & - & 14 & 14 & 0.2 & 1.0 & 10 & 5.0 & 2.0 \\
\hline
\end{tabular}




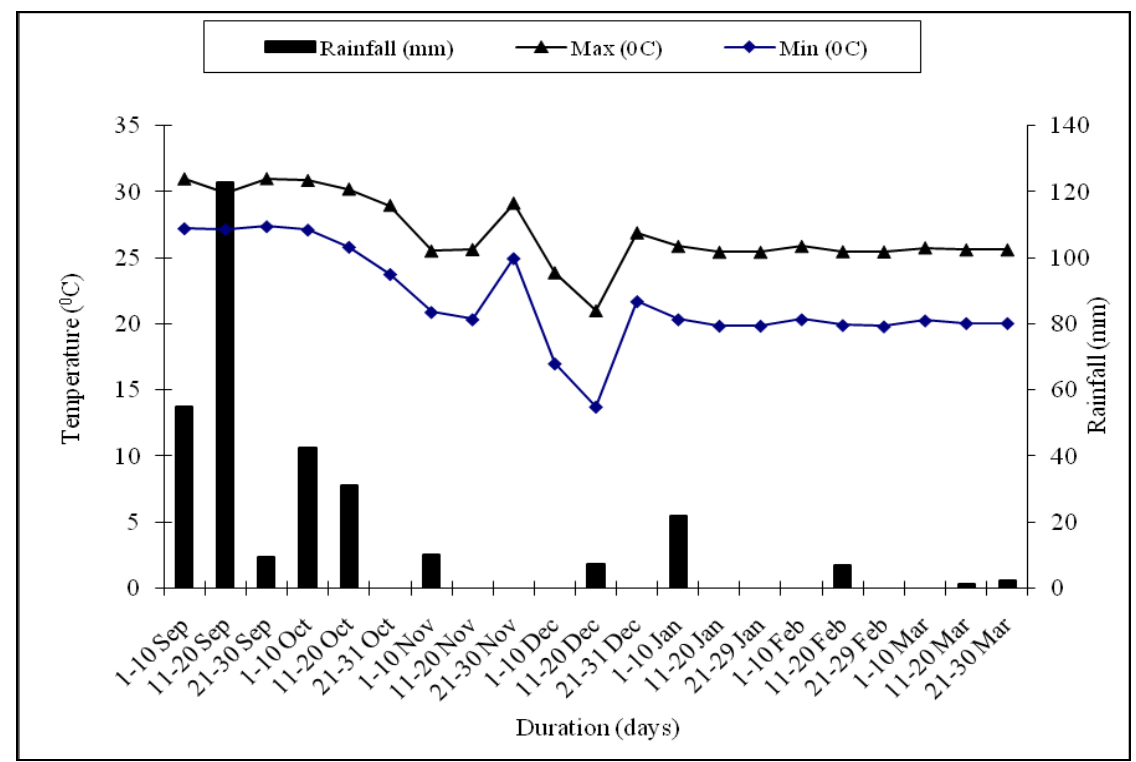

Fig. 1 Average maximum and minimum air temperature $\left({ }^{\circ} \mathrm{C}\right)$ and total rainfall (mm) during the growing period (pooled data of 2011-2012 and 2012-2013)

(Source: Bangladesh Sugarcane Research Institute, Ishurdi, Pabna).

\section{Results and Discussion}

Significant variation was not found in years. So, pooled analysis on seed yield and yield attributes were done and discussed accordingly.

\section{Effect of sowing date on plant character and seed yield of cauliflower}

Plant height was significantly affected by sowing dates. The maximum plant height $(94 \mathrm{~cm})$ was measured from 20 September sowing which was statistically similar to 1 October sowing $(92 \mathrm{~cm})$ and the minimum plant height $(84 \mathrm{~cm})$ from 20 October sowing (Table 1). This might be due to favourable conditions prevailing during the growing period when planted earlier i.e., 1 October and also due to longer growth experienced by plants resulted from the seeds sown earlier. Similar results were obtained under different climatic conditions as influenced sowing time by Jaiswal et al., (1996). Number of plants $\mathrm{m}^{-2}$ was same (2.83) in all the sowing dates as no plants were dead in the later stage and in very early stage of planting dead plants were replaced with the same aged seedlings. Early flowering was enhanced by different sowing dates. The earliest $50 \%$ flowering (105 days) occurred on 20 October sowing whereas, delayed flowering (120 days) on 20 September sowing. Sowing on 20 October took shorter cool period 
for vegetative growth and it turned quickly for reproductive phase. These results coincide with the findings of Castillo et al., (1992) who reported that the short growing cycle in winter enhanced flowering. Similar trend was observed in case of seed harvest. Early sowing (20 September) required the maximum days (176) whereas, the last sowing (20 October) required the minimum days (161) for pod harvest. Early sowing received long cool period for growth of the plant resulted delayed flowering as well as harvesting. The maximum number of branches plant $^{-1}$ (11.84) was obtained from 1 October sowing followed by 20 September sowing (10.86) and the minimum number of branches plant ${ }^{-1}$ (9.10) from 10 October sowing. Being a thermo sensitive plant, the early planted plant received comparatively low temperature during vegetative growth which produced bigger sized head which ultimately produced branches (Kanwar, 1996). Number of pods plant $^{-1}$ is an important yield contributing factor for cauliflower seed production, which is significantly influenced by the prevailing growing conditions of a crop. The maximum number of pods plant ${ }^{-1}$ was produced from 1 October sowing (1263) which was statistically similar to 20 September sowing (1238) and the lowest was produced from 20 October sowing (863). These results are in agreement with the findings of Incalcaterr et al., (2000). The maximum number of seeds $\operatorname{pod}^{-1}(16.22)$ was recorded from 1 October sowing and while the minimum number of seeds pod $^{-1}$ (14.47) was recorded from 20 September sowing which was statistically similar to 10 October sowing. This might be due to plants sowing on 1 October took the optimum growing period which produced the optimum size of pod as well as the maximum number of seeds pod $^{-1}$. Patil et al., (1995) reported that plants grown in early winter produced large sized pod and increased number of seeds pod ${ }^{-1}$ because of proper growth and development of the cauliflower plants. There was no significantly difference among the sowing dates in respect of 1000-seed weight. However, 1000-seed weight was decreased with the advancement of date from 1 October sowing. The highest seed yield (361.69 $\mathrm{kgha}^{-1}$ ) was obtained from 1 October sowing possibly due to higher number of branches as well as pods plant ${ }^{-1}$. Moreover, by sowing the crop on 1 October, the phonological phase of plant influenced to thermal regimes conceded with optimum temperature (Fig.1). These results are almost similar to Gurusamy (1999) who reported that early sowing increased head size and produced the highest seed yield. Significantly the lower seed yield (188.54 kgha ${ }^{1}$ ) was obtained from 20 October sowing. Shorter growing period experienced by the crop sown on 20 October caused reduction in seed yield. Castillo et al., (1992) also observed that the short growing cycle in winter cultivars both stages (curd and seed yield) were decreased at later sowing dates. 


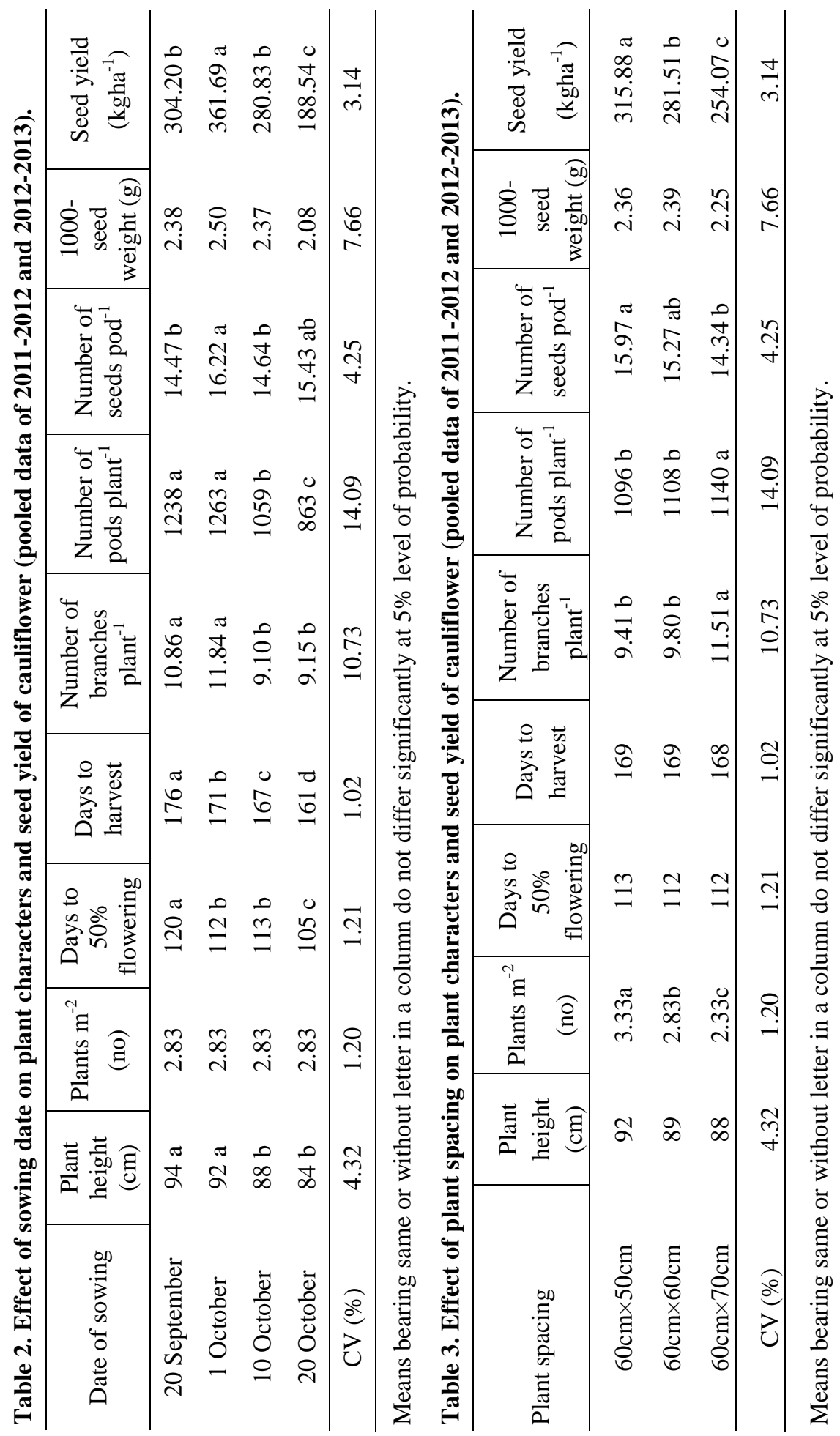




\section{Effect of plant spacing on plant characters and seed yield of cauliflower}

Number of branches plant ${ }^{-1}$, number of pods plant ${ }^{-1}$, number of seeds $\operatorname{pod}^{-1}$ and seed yield ha ${ }^{-1}$ were significantly affected by plant spacing. Number of plants $\mathrm{m}^{-2}$ was maximum $(3.33)$ in $60 \mathrm{~cm} \times 70 \mathrm{~cm}$ followed by $60 \mathrm{~cm} \times 60 \mathrm{~cm}(2.83)$ and minimum in $60 \mathrm{~cm} \times 70 \mathrm{~cm}(2.33)$ according to the treatments. Variation of plant population did not show significant effect in respect of days to $50 \%$ flowering, days to harvest, plant height and 1000-seed weight (Table3). The highest number of branches plant ${ }^{-1}(11.51)$ was recorded from $60 \mathrm{~cm} \times 70 \mathrm{~cm}$ spacing and the minimum number of branches plant ${ }^{-1}(9.41)$ from $60 \mathrm{~cm} \times 50 \mathrm{~cm}$ spacing. This may be due to the wider spacing where plant received more nutrients, space, aeration and sunlight for better curd growth and development which increased curd diameter and enhanced more branching. Similar results were quoted by Rahman et al., (2007). The highest number of pods plant ${ }^{-1}$ (1140) was produced from $60 \mathrm{~cm} \times 70 \mathrm{~cm}$ spacing, while closer spacing $(60 \mathrm{~cm} \times 50 \mathrm{~cm})$ produced the minimum number of pods plant ${ }^{-1}(1096)$. The more branches plant ${ }^{-1}$ produce more number of pods per plant. On the contrary, the maximum number of seeds plant ${ }^{-1}$ (15.97) was counted from $60 \mathrm{~cm} \times 50 \mathrm{~cm}$ spacing which was statistically similar to $60 \mathrm{~cm} \times 60 \mathrm{~cm}$ spacing and the minimum number of seeds plant $^{-1}$ (14.34) was counted from wider spacing $(60 \mathrm{~cm} \times 70 \mathrm{~cm})$. The plants which produced less number of pods required more nutrient and produce comparatively long pod resulted more number of seeds plant ${ }^{-1}$. Plant spacing had a significant effect on seed production of cauliflower. The highest seed yield $\left(315.88 \mathrm{kgha}^{-1}\right)$ was obtained from $60 \mathrm{~cm} \times 50 \mathrm{~cm}$ plant spacing due to closer spacing accumulates more number of plants which ultimately increased seed yield. Increasing the plants number plot $^{-1}$ decreased the head size but increased the seed yield. Sharma and Arora (1984) reported that curd yield as well as seed yield increased with increasing plant density. There was a trend to decrease seed yield with the increase in plant spacing.

\section{Combined effect of sowing date and plant spacing on plant characters and seed yield of cauliflower}

Most of the parameters were not significant except number of pods plant $^{-1}$ and seed yield ha ${ }^{-1}$ of cauliflower (Table 4). The maximum number of pods plant ${ }^{-1}$ (1392) was counted from 1 October sowing with $60 \mathrm{~cm} \times 70 \mathrm{~cm}$ spacing, whereas the minimum number of pods plant ${ }^{-1}$ (840) from 20 October sowing with $60 \mathrm{~cm} \times 70 \mathrm{~cm}$ spacing. The highest yield $\left(414.81 \mathrm{kgha}^{-1}\right)$ was obtained from 1 October sowing with $60 \mathrm{~cm} \times 50 \mathrm{~cm}$ spacing due to more number of seeds pod $^{-1}$ though branches plant ${ }^{-1}$ and pods plant ${ }^{-1}$ lower than I October sowing with wider spacing $(60 \mathrm{~cm} \times 70 \mathrm{~cm})$. The higher yield in above treatment is due to better plant survival owing to the favourable conditions for growth and development of plant and the closer spacing accommodates more number of plants per unit area. Similar results were reported by Azizur Rehman and Nawab Ali (2000). Seed yield was considerably decreased in late sowing (20 October). 


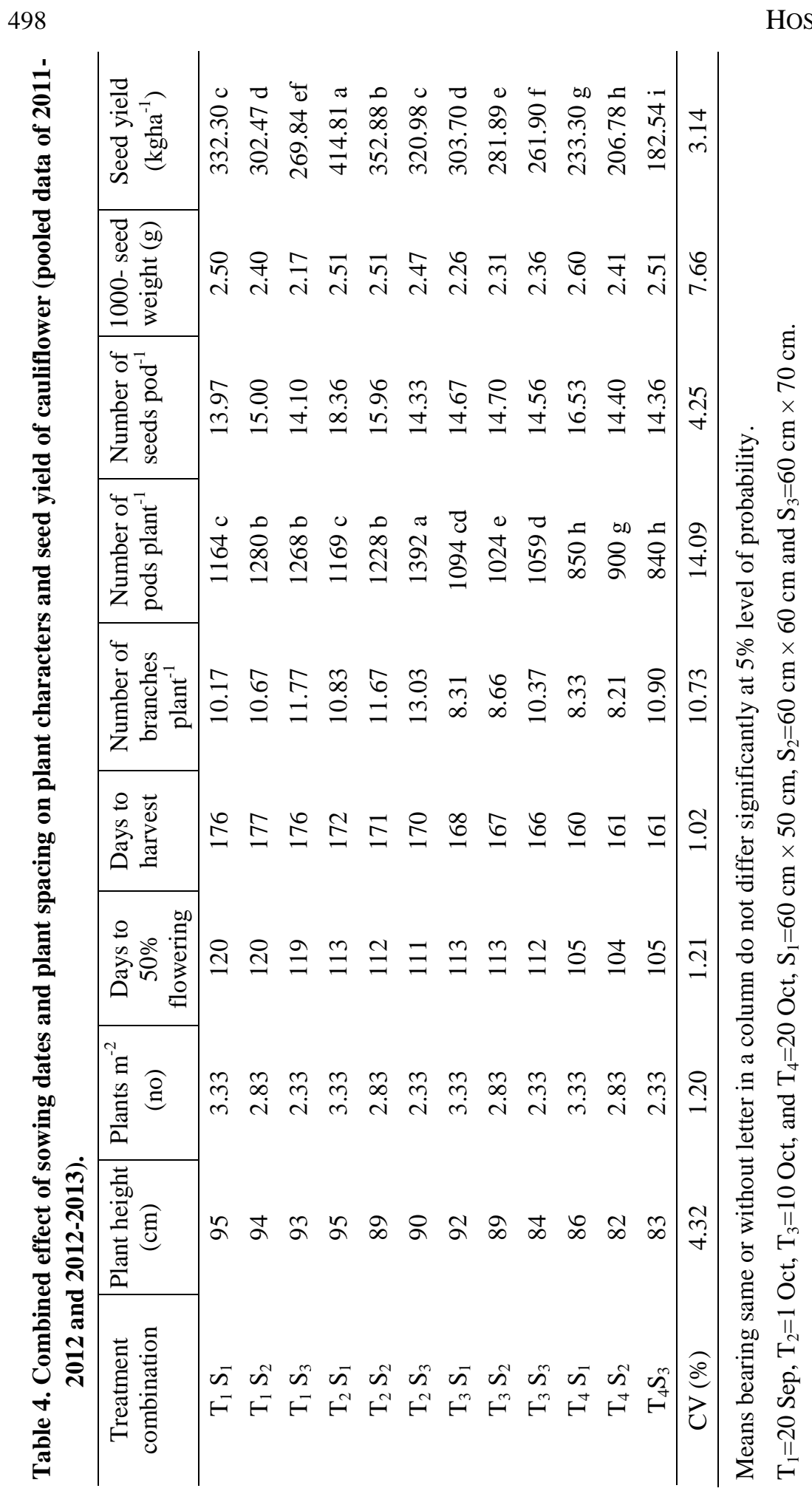




\section{Economic performance}

The economic performances of sowing date and plant spacing on seed production of cauliflower are presented in Table 5. The highest gross return (Tk. 4148100 $\mathrm{ha}^{-1}$ ) and gross margin (Tk. $3967125 \mathrm{ha}^{-1}$ ) was obtained from the crop sown on 1 October with $60 \mathrm{~cm} \times 50 \mathrm{~cm}$ plant spacing. Maximum benefit cost ratio (23.18) was also obtained from the same treatment combination. Hence early sowing (1 October) with $60 \mathrm{~cm} \times 50 \mathrm{~cm}$ plant spacing would be economically profitable for cauliflower seed production.

Table 5. Benefit-cost analysis of cauliflower seed production under different sowing dates and plant spacing (pooled data of 2011-2012 and 2012-2013).

\begin{tabular}{ccccccc}
\hline Treatments & $\begin{array}{c}\text { Seed yield } \\
\left(\text { kgha }^{-1}\right)\end{array}$ & $\begin{array}{c}\text { Gross return } \\
\left(\text { Tkha }^{-1}\right)\end{array}$ & $\begin{array}{c}\text { Cost of } \\
\text { production } \\
(\text { Tk/ha })\end{array}$ & $\begin{array}{c}\text { Net margin } \\
(\mathrm{Tk} / \mathrm{ha})\end{array}$ & BCR \\
\hline $\mathrm{T}_{1} \mathrm{~S}_{1}$ & 332.30 & 3323000 & 178975 & 3144025 & 18.57 \\
$\mathrm{~T}_{1} \mathrm{~S}_{2}$ & 302.47 & 3024700 & 178975 & 2845725 & 16.90 \\
$\mathrm{~T}_{1} \mathrm{~S}_{3}$ & 269.84 & 2698400 & 178975 & 2519425 & 15.08 \\
$\mathrm{~T}_{2} \mathrm{~S}_{1}$ & 414.81 & 4148100 & 178975 & 3969125 & $\mathbf{2 3 . 1 8}$ \\
$\mathrm{T}_{2} \mathrm{~S}_{2}$ & 352.88 & 3528800 & 178975 & 3349825 & 19.72 \\
$\mathrm{~T}_{2} \mathrm{~S}_{3}$ & 320.98 & 3209800 & 178975 & 3030825 & 17.93 \\
$\mathrm{~T}_{3} \mathrm{~S}_{1}$ & 303.70 & 3037000 & 178975 & 2858025 & 16.97 \\
$\mathrm{~T}_{3} \mathrm{~S}_{2}$ & 281.89 & 2818900 & 178975 & 2639925 & 15.75 \\
$\mathrm{~T}_{3} \mathrm{~S}_{3}$ & 261.90 & 2619000 & 178975 & 2440025 & 14.63 \\
$\mathrm{~T}_{4} \mathrm{~S}_{1}$ & 233.30 & 2333000 & 178975 & 2154025 & 13.04 \\
$\mathrm{~T}_{4} \mathrm{~S}_{2}$ & 206.78 & 2067800 & 178975 & 1888825 & 11.55 \\
$\mathrm{~T}_{4} \mathrm{~S}_{3}$ & 182.54 & 1825400 & 178975 & 1646425 & 10.20 \\
\hline
\end{tabular}

$\mathrm{T}_{1}=20$ September, $\mathrm{T}_{2}=1$ October, $\mathrm{T}_{3}=10$ October, $\mathrm{T}_{4}=20$ October, $\mathrm{S}_{1}=60 \mathrm{~cm} \times 50 \mathrm{~cm}$, $\mathrm{S}_{2}=60 \mathrm{~cm} \times 60 \mathrm{~cm}$ and $\mathrm{S}_{3}=60 \mathrm{~cm} \times 70 \mathrm{~cm}$

Marked price: Seed $=$ Tk. $10,000 \mathrm{~kg}^{-1}$ (OP variety)

\section{Conclusion}

The study revealed that the seed yield of cauliflower was significantly affected by different sowing dates. Early October sowing with $60 \mathrm{~cm} \times 50 \mathrm{~cm}$ plant spacing produced the highest seed yield due to higher yield attributes as well as prevail longer period of cool. So, early sowing (1October) with $60 \mathrm{~cm} \times 50 \mathrm{~cm}$ plant spacing would be economically profitable for enhancing growth parameters and seed production of cauliflower in North-western part of Bangladesh. 


\section{References}

Alam M, Farooque A M, Nuruzzaman M and Jamaluddin A F M. 2010. Effect of sowing time on growth and yield of three radish varieties. Bangladesh Res. Pub. J. 3(3): 998-1006.

Anonymous. 2007. The year book of Agricultural Statistics of Bangladesh. Bangladesh Bureau of Statistics, Ministry of Planning, Govt. People's Repub. Bangladesh.

Azizur Rehman and Nawab Ali. 2000. Effect of plant spacing and sowing time on yield of turnip crop. Sarhad J Agri. 16(60: 775-779.

Baloch A F. 1994. Vegetable Crops Horticulture. National Book Foundation, Islamabad. Pp. 489-538.

Castillo H, Quintanilla C and Melillo C. 1992. Effect of sowing date on curd and seed yield in four cauliflower cultivars. Conf. paper of international Soc. for Tropical Hort. 7-12.

Din F, Qasim M, Elahi N and Faridullah. 2007. Responce of different sowing dates on the growth and yield of cauliflower. Sarhad J. Agric. 23(2):289-291.

Gurusamy C. 1999. Effect of stage of harvesting on seed yield and quality of cauliflower. Indian Seed Sci. and Tech. 27(3): 29-936.

Incalcaterra G, Iapichino G, Stoffela P J, Cantliffej D J and Damato G. 2000. Sowing time influences cauliflower seed production. Italian Acta Hort. 533: 45-52.

Jaiswal J P, Subedi P P and Bhattarai S P. 1996. Findings of seed production study on cauliflower. Working paper of Agric. Res. Center, Nepal. 14 p.

Kanwar J S. 1996. Effect of sowing times on the curd size and seed yield of cauliflower. Annual report of Punjab Agric. Univ. India 22(1): 69-71.

Lavanya A V N, Sudhavani V, Reddy P S and Chaitanya K. 2014. Effect of sowing dates and spacing on growth and root yield of radish cv. pusa chetki. Plant Archives 14(1):619-623.

Pandita V K, Scrana Chaudry D and Vinod. 2005. Seed productivity and quality in relation to plant spacing in carrot. Indian J. Agri. Sci. 75(11): 722-724.

Patil J D, Ranpise S A and Jadhav S B. 1995. Effect of spacing and date of sowing on yield of different cultivars of cauliflower. Agric. Madras J India 82(11): 613-614.

Rahman M. Iqbal M. Jilani M S. and Waseem K. 2007. Effect of different plant spacing on the productiion of cauliflower (Brassica oleracea var botrytis). Pakistan J of Bio. Sci. 10: 4531-4534.

Sharma R P. and Arora P N. 1984. Response of mid season cauliflower to rates and time of nitrogen application and plant density. Indian J. Agron. 29: 468-470. 